\title{
Penampilan Galur Harapan F9 Padi Beras Hitam Hasil Persilangan Baas Selem dan Situ Patenggang
}

\section{Performances of F9 Elite Lines of Black Rice Crossed between Baas Selem and Situ Patenggang}

\author{
${ }^{* 1}$ IGP Muliarta Aryana, ${ }^{1}$ AA. Sudharmawan, ${ }^{1}$ Sumarjan, ${ }^{1}$ Dwi Ratna Anugrahwati \\ ${ }^{1}$ Program Studi Agroekoteknologi Fakultas Pertanian, \\ Universitas Mataram, INDONESIA \\ *E-mail: muliarta1@yahoo.co.id
}

Manuscript received: 04-10-2017. Accepted: 20-12- 2017

\begin{abstract}
ABSTRAK
Persilangan antara dua tetua dengan masing-masing keunggulan dan kemudian dilakukan seleksi akan menghasilkan galur harapan. Penelitian ini bertujuan untuk mengetahui penampilan galur harapan F9 padi beras hitam hasil persilangan "Baas Selem vs Situ Patenggang" yang berdaya hasil tinggi. Percobaan dilaksanakan di lahan sawah di desa Nyur Lembang, kabupaten Lombok Barat pada April-Agustus 2017. Percobaan ditata dalam Rancangan Acak Kelompok (RAK) dengan 10 genotipe padi sebagai perlakuan yang diulang tiga kali yaitu 7 galur harapan F9 padi beras hitam, 2 tetua (Situ Patenggang dan Baas Selem), dan 1 varietas pembanding peka kekeringan (IR20). Penanaman secara sistem gogo pada petak berukuran $3 \times 4 \mathrm{~m}$ berjarak tanam $25 \times 25 \mathrm{~cm}$. Pengairan diberikan bila tanaman pembanding menunjukkan gejala daun menggulung. Hasil penelitian menunjukkan bahwa galur G1(F9 2/1/1) relatif memiliki daya hasil tinggi yaitu 6.53 ton ha ${ }^{-1}$ dengan karakter berat gabah per rumpun (55.68 gram), jumlah gabah berisi per malai (122.45 butir), panjang malai $(24.08 \mathrm{~cm})$ dan jumlah anakan produktif per rumpun sebanyak17.53 batang; dan galur G7 (F9 3/4/1) berdaya hasil 6.35 ton ha ${ }^{-1}$ dengan karakter berat gabah per rumpun (50.47 gram), jumlah gabah berisi per malai (124.15 butir), panjang malai $(24.02 \mathrm{~cm})$ dan jumlah anakan produktif per rumpun sebanyak 18.30 batang.
\end{abstract}

Kata kunci: gabah, bulk, seleksi, sistim gogo

\begin{abstract}
Crossing between two parents with each advantages and then selection will produce a elite line. The aim of this research is to know the appearance of F9 rice line of black rice from "Baas Selem vs Situ Patenggang" crossing which has high yield. The experiment was conducted on rice field in Nyur Lembang village, West Lombok district during April to August 2017. The experiment was arranged in Randomized Block Design of 10 rice genotypes treatment with three replications i.g F9 lines of black rice, 2 parents (Situ Patenggang and Baas Selem), and 1 varieties of drought-sensitive comparison (IR20). Gogo planting system in a plot of $3 \times 4 \mathrm{~m}$ with spacing $25 \times 25 \mathrm{~cm}$. Watering was given when comparative plants (IR20) show symptoms of leaf curl. The results shows that the G1 line (F9 2/1/1)
\end{abstract}


had relatively high yieldof 6.53 ton $^{-1}$ with weight of grain per clump (55.68 gram), grain per panicle (122.45 grains ), panicle length $(24.08 \mathrm{~cm})$, and number of productive tillers per clump of 17.53 stalks; and G7 line (F9 3/4/1) yielded 6.35 ton ha ${ }^{-1}$ with grain weight per clump (50.47 gram), number of grains per panicle (124.15 grains), panicle length $(24.02 \mathrm{~cm})$, and number of productive tiller per clump as much as 18,30 stalks.

Keywords: grain, bulk, selection, gogo system

\section{PENDAHULUAN}

Beras hitam merupakan padi fungsional yang mengandung pigmen paling baik, berbeda dengan beras putih atau beras warna lain. Keberadaan beras hitam semakin langka akibatdidominasi oleh penanaman padi varietas unggul tipe modern, ideal maupun hibrida warna putih. Beras hitam memiliki rasa dan aroma yang baik dengan penampilan yang spesifik dan unik sehingga menimbulkan selera makan.

Warna beras diatur secara genetik, dan dapat berbeda akibat perbedaan gen yang mengatur warna aleuron, endospermia, dan komposisi pati pada endospermia. Pada beras hitam, aleuron dan endospermia memproduksi antosianin dengan intensitas tinggi sehingga warna beras menjadi ungu pekat mendekati hitam. Analisis laboratorium menunjukan bahwa beras hitam mengandung protein $5.51 \%$, lemak $1.85 \%$, amilosa $22.97 \%$, amilopektin 51.54 $\%$, dan pati $14.52 \%$, beta-karotin $804.16 \mathrm{mg} / 100$ gram, besi $15.52 \mathrm{ppm}$ dan antosianin 393.93 ppm. Oleh karena itu, beras hitam memiliki khasiat yang lebih baik dibanding beras merah atau beras warna lain. Beras hitam berkhasiat meningkatkan daya tahan tubuh terhadap penyakit, memperbaiki kerusakan sel hati, mencegah gangguan fungsi ginjal, mencegah kanker/tumor, memperlambat penuaan, sebagai antioksidan, membersihkan kolesterol dalam darah, dan mencegah anemia.Seiring dengan peningkatan taraf hidup masyarakat dan kesadaran akan pentingnya kesehatan, maka konsumsi beras hitam semakin meningkat (Hermanto, 2008; Suardi dan Ridwan, 2009; Kristamtini dan Purwaningsih, 2010; Muliarta dkk, 2016).

Lahan kering merupakan salah satu lahan marjinal yang berpotensial untuk meningkatkan produksi padi guna pemenuhan pangan nasional. Luas lahan kering di Indonesia mencapai lebih dari 8 juta ha yang dapat tertanami padi gogo. Potensi lahan ini belum termanfaatkan secara optimal. Laporan Deptan (2011) menyatakan luasan panen padi gogo pada 2010 hanya mencapai 1.13 juta ha dengan produksi 3.45 juta ton dengan produktivitas 3.04 ton per ha. Produktifitas padi gogo ini jauh lebih rendah dibandingkan dengan padi sawah yang mencapai 5.20 tonha $^{-1}$. Sehingga produktivitas padi gogo yang toleran kekeringan perlu ditingkatkan, dan salah satunya melalui pembentukan varietas unggul baru. Produktivitas yang tinggi ditentukan oleh karakter pertumbuhan yang menentukan hasil seperti tinggi tanaman, jumlah anakan produktif, umur berbunga dan umur panen (Anwar et al., 1986), dan karakter komponen hasil seperti jumlah gabah per malai, persentase gabah isi per malai dan bobot 1000 biji (Taslim et al., 1989)

Perbaikan varietas padi beras hitam toleran kekeringan dan berdaya hasil tinggi di Indonesia belum mendapat perhatian serius. Saat ini petani lahan kering masih menggunakan varietas lokal berumur dalam dan berdaya hasil rendah, sekitar 2 ton ha ${ }^{-1}$. Oleh karena itu, telah dilakukan persilangan tunggal antara varietas unggul Situ Patenggang yang memiliki toleransi kekeringan dan daya hasil tinggi sebagai tetua jantan dengan kultivar beras hitam "Baas Selem" dengan kandungan antosianin tinggi dan daya hasil rendah sebagai tetua 
betina. Syukur dkk. (2012) menyatakan perluasan keragaman genetik dapat dilakukan melalui hibridisasi (persilangan). Kemudian terhadap populasi hasil persilangan dilakukan seleksi menggunakan metode seleksi bulk hingga zuriat F9. Febrianti (2013) menyatakan bahwa metode seleksi bulk merupakan salah satu prosedur untuk silang dalam dari populasi yang bersegregasi sampai tingkat perubahan sifat homozigot tercapai.

Untuk menghasilkan galur galur harapan yang superior sebagai calon untuk menghasilkan calon varietas unggul baru yang berpotensi hasil tinggi dan adaptif pada lingkungan kering maka perlu dilakukan penyaringan genotipe melalui uji potensi hasil galur harapan padi beras hitam fungsional. Tujuan penelitian ini adalah untuk mengetahui penampilan galur harapan F9 padi beras hitam hasil persilangan "Baas Selem vs Situ Patenggang" yang berdaya hasil tinggi.

\section{BAHAN DAN METODE}

Percobaandilaksanakan dilahan sawah desa Nyur Lembang Kecamatan Narmada kabupaten Lombok Barat pada April-Agustus 2017. Percobaan ditata dalam Rancangan Acak Kelompok (RAK) dengan 10 genotipe padi sebagai perlakuan yang diulang tiga kali, yaitu7 galur harapan padi beras hitam, 2 tetua (SituPatenggang dan Baas Selem), dan 1 varietas pembanding (IR20).

Penanaman dilakukan pada petakan berukuran $3 \times 4 \mathrm{~m}$, berjarak tanam $25 \times 25$ cmsecara gogo. Pemupukan dilakukan pada umur 7 hst dengan Phonska dosis $300 \mathrm{~kg} \mathrm{ha}^{-1}$, dan Urea diberikan pada 30 hst dan 50 hst dengan dosis masing-masing $100 \mathrm{~kg} \mathrm{ha}^{-1}$. Pengairan diberikan bila tanaman pembanding (IR20) menunjukkan gejala daun menggulung.

Pengamatan dilakukan dengan pengambilan tanaman sampel sebanyak 10 tanaman per perlakuan tiap blok yang dilakukan secara acak. Parameter yang diamati meliputi umur panen, tinggi tanaman, jumlah anakan produktif per rumpun, jumlah anakan non produktif per rumpun, panjang malai, jumlah gabah berisi per malai, jumlah gabah hampa per malai, bobot 100 butir gabah ,bobot gabah per rumpun, dan hasil gabah ton ha ${ }^{-1}$ (konversi dari luasan panen $1 \mathrm{~m}^{2}$ ).

Data hasil pengamatan dianalisis dengan menggunakan analisis keragaman pada taraf nyata 5\% dan sumber keragaman. Kemudian diuji lanjut dengan DMRT pada taraf nyata yang sama dengan program SAS.

\section{HASIL DAN PEMBAHASAN}

Berdasarkan hasil analisis ragam (Tabel 1) terhadap parameteryang diamatidari 7 galur yang diuji dan 1 varietas pembanding serta 2 tetua menunjukkan parameteryang berbeda nyata adalah, umur panen, tinggi tanaman, jumlah anakan non produktif, jumlah gabah berisi dan hampa per malai dan hasil. Sedangkan parameter yang berbeda tidak nyata yaitu jumlah anakan produktif per rumpun, panjang malai dan berat gabah per rumpun.

Pada pengamatan umur panen (Tabel 2) tampak bahwa dari 7 galur yang diuji dan 1 varietas pembanding serta 2 tetua memberikan pengaruh yang nyata. Umur panen dari genotipe yang diuji bervariasi antara 106.00 hingga 120.00 hst dengan reratanya 116.17 hst. Galur G4 dan G7 menunjukkan perbedaan yang nyata dengan tetua G8 (Situ Patenggang) sedangkan galur G1 berbeda nyata dengan G9 (Baas Selem) yang merupakan galur paling 
cepat panen jika dibandingkan dengan tetua Baas selem. Dari seluruh genotipe yang diujikan tanaman yang paling cepat panen adalah varietas pembanding G10(IR 20)

Tabel 1. Hasil analisis ragam parametergenotipe padi beras hitam

\begin{tabular}{lccc}
\hline \multicolumn{1}{c}{ Variabel } & F hitung & Prob & Notasi \\
\hline Umur Panen & 13.37 & 0.0003 & $\mathrm{~s}$ \\
Tinggi Tanaman & 5.91 & 0.0007 & $\mathrm{~s}$ \\
Jumlah Anakan Produktif Per Rumpun & 1.69 & 0.1624 & $\mathrm{~ns}$ \\
Jumlah Anakan Non Produktif Per Rumpun & 8.03 & 0.0001 & $\mathrm{~s}$ \\
Panjang Malai & 0.47 & 0.8699 & $\mathrm{~ns}$ \\
Jumlah Gabah Berisi Per Malai & 2.48 & 0.0481 & $\mathrm{~s}$ \\
Jumlah Gabah Hampa Per Malai & 4.23 & 0.0045 & $\mathrm{~s}$ \\
Berat 100 Butir & 6.15 & 0.0005 & $\mathrm{~s}$ \\
Berat Gabah Per Rumpun & 1.99 & 0.1019 & $\mathrm{~ns}$ \\
Hasil & 6.69 & 0.0003 & $\mathrm{~s}$ \\
& & & \\
\hline
\end{tabular}

Keterangan: $\mathrm{s}=$ signifikan; $\mathrm{ns}=$ non signifikan

Tabel 2. Hasil uji lanjut parameter umur berbunga, tinggi tanaman, jumlah anakan produktif dan non produktif per rumpun dan panjang malai genotipe padi

\begin{tabular}{lccccc}
\hline \multicolumn{1}{c}{ Genotipe } & UP & TT & JAP & JANP & PM \\
\hline G1 (F9 2/1/1) & $113.33 \mathrm{c}$ & $112.23 \mathrm{a}$ & 17.53 & $0.87 \mathrm{~b}$ & 24.08 \\
G2 (F9 2/1/2) & $117.33 \mathrm{ab}$ & $100.83 \mathrm{bc}$ & 16.63 & $0.53 \mathrm{~b}$ & 23.93 \\
G3 (F9 3/1) & $117.00 \mathrm{ab}$ & $99.53 \mathrm{bc}$ & 16.27 & $1.13 \mathrm{~b}$ & 23.52 \\
G4 (F9 3/2/2) & $119.67 \mathrm{a}$ & $89.77 \mathrm{~cd}$ & 14.53 & $0.20 \mathrm{~b}$ & 23.32 \\
G5 (F9 3/2/1) & $118.33 \mathrm{ab}$ & $90.07 \mathrm{~cd}$ & 14.17 & $0.93 \mathrm{~b}$ & 23.52 \\
G6 (F9 2/3) & $116.67 \mathrm{abc}$ & $107.57 \mathrm{ab}$ & 13.17 & $1.13 \mathrm{~b}$ & 23.47 \\
G7 (F9 3/4/1) & $120.00 \mathrm{a}$ & $96.03 \mathrm{~cd}$ & 18.30 & $0.77 \mathrm{~b}$ & 24.02 \\
G8 (Situ Patenggang) & $115.00 \mathrm{bc}$ & $90.73 \mathrm{~cd}$ & 12.80 & $1.70 \mathrm{~b}$ & 23.07 \\
G9 (Baas Selem ) & $118.33 \mathrm{ab}$ & $94.83 \mathrm{~cd}$ & 16.50 & $0.70 \mathrm{~b}$ & 23.29 \\
G10 (IR 20) & $106.00 \mathrm{~d}$ & $84.50 \mathrm{~d}$ & 13.83 & $6.40 \mathrm{a}$ & 23.27 \\
\hline Rerata & 116.17 & 96.61 & 15.37 & 1.40 & 23.55 \\
Maksimum & 120.00 & 112.23 & 18.30 & 6.40 & 24.08 \\
Minimum & 106.00 & 84.50 & 12.80 & 0.20 & 23.07 \\
\hline
\end{tabular}

Keterangan: UP: umur panen (hss); TT: tinggi tanaman (cm); JAP: jumlah anakan produktif per rumpun (batang); JANP: jumlah anakan non produktif per rumpun (batang); PM: panjang malai (cm). Angka yang diikuti oleh huruf yang sama pada kolom yang sama menunjukkan berbeda tidak nyata menurut hasil uji DMRT pada taraf nyata $5 \%$

Pada umumnya padi yang lebih cepat berbunga akan diikuti pula dengan lebih awal panennya. Untuk padi jenis cere periode yang dibutuhkan untuk waktu panen adalah sekitar 30-35 hari setelah berbunga.

Menurut Siregar (1981), menggolongkan umur panen menjadi empat golongan yaitu Sangat Genjah (<110 hari), Genjah (110-115 hari), Sedang (115-125 hari), dan Dalam (125150 hari). Dari kriteria tersebut menunjukkan bahwa galur G1 dan tetua Situ Patenggang (G8) genjah, sedangkan galur lainnya dan tetua Baas Selem (G9) tergolong umur sedang. Varietas pembanding IR20 (G10) tergolong berumur sangat genjah. 
Galur G1 dan G6 berbeda nyata dengan kedua tetuanya pada karakter tinggi tanaman. Galur tersebut menunjukkan tanaman tertinggi dibandingkan dengan kedua tetuanya. Diantara galur yang diujikan nampak galur G1 paling tinggi kecuali pada G6. Varietas IR20 (G10) menunjukkan tanaman paling rendah dibandingkan dengan G1,G2, G3,dan G6. Tabel 2. menunjukkan bahwa tinggi tanaman bervariasi antara $84.50 \mathrm{~cm}$ hingga $112.23 \mathrm{~cm}$, dengan tinggi reratanya sebesar 96.61. Tinggi tanaman paling tinggi dijumpai pada G1 $(112.23 \mathrm{~cm})$ dan galur ini memiliki tinggi tanaman yang sama dengan G6.

Departemen Pertanian (1983), menggolongkan tinggi tanaman menjadi tiga golongan yaitu Pendek $(<110 \mathrm{~cm})$, Sedang $(110-130 \mathrm{~cm})$, dan Tinggi $(>130 \mathrm{~cm})$. Berdasarkan penggolongan tinggi tanaman tersebut maka galur yang diuji, tetua dan varietas pembanding tergolong pendek kecuali G1. Tinggi tanaman padi $112.23 \mathrm{~cm}$ adalah tergolong memiliki tinggi tanaman sedang. Menurut Suparyono dan Setyono (1993), bahwa tanaman yang pendek merupakan salah satu kriteria keunggulan padi. Tanaman padi yang memiliki batang pendek sangat baik karena dapat menyebabkan tanaman tidak mudah rebah akibat gangguan faktor lingkungan seperti hujan dan angin.

Jumlah anakan produktif per rumpun merupakan salah satu pendukung atau komponen hasil. Berdasarkan hasil analisis ragam dari 7 galur yang diuji dan 1 varietas pembanding serta 2 tetua memberikan pengaruh yang tidak nyata terhadap jumlah anakan produktif per rumpun. Tabel 2. menunjukkan bahwa jumlah anakan produktif per rumpun bervariasi antara 12.80 batang hingga 18.30 batang, dengan jumlah reratanya sebesar 15.37 batang. Jumlah anakan produktif per rumpun tertinggi nampak pada galur G7 (18,30 batang).

Sunihardi dan Hermanto (2004), menggolongkan jumlah anakan produktif menjadi empat golongan yaitu Sedikit (9-11 batang), Sedang (12-14 batang), Banyak (15-20 batang), dan Sangat Banyak (>20 batang). Berdasarkan kriteria tersebut galur G4, G5, dan G61, tetua Situ Patenggang (G8) dan IR20 tergolong sedang. Galur G1, G2, G3, G7 dan Baas Selem (G9) tergolong memiliki anakan banyak. Jumlah anakan produktif berpengaruh terhadap jumlah gabah per tanaman dan mempengaruhi hasil produksi, semakin banyak anakan yang produktif maka produksi akan semakin tinggi. Menurut Silitonga dan Harahap (1998), bahwa genotipe-genotipe yang memiliki umur lebih panjang akan menghasilkan jumlah anakan yang lebih banyak tetapi jumlah anakan yang tidak produktifpun akan meningkat, karena masa vegetatif yang lama akan mengakibatkan bertambahnya jumlah anakan yang terbentuk, akan tetapi jumlah anakan produktif cendrung tidak akan meningkat. Selanjutnya menurut Yoshida (1981) jarak tanam, cahaya, pasokan hara, dan kondisi kultur mempengaruhi pembentukan anakan.

Jumlah anakan non produktif per rumpun menunjukkan pengaruh tidak nyata antar galur maupun dengan tetua (Situng Patenggang dan Baas Selem) kecuali dengan varietas pembanding IR20 (G10). Pada Tabel 2. tampak bahwa jumlah anakan non produktif bervariasi antara 0.20 batang hingga 6.40 batang per rumpunnya, dengan reratanya 1.4 batang. Jumlah anakan non produktif tertinggi nampak pada G10 (IR20) 6.40 batang.

Anakan non produktif merupakan salah satu faktor yang mempengaruhi hasil. Semakin banyak anakan non produktif akan menyebabkan lingkungan mikro yang semakin lembab sehingga sangat baik untuk perkembangan hama dan penyakit (Thamrin et al., 2010).

Berdasarkan hasil analisis ragam tampak bahwa semua galur, tetua dan varietas pembanding yang diuji berpengaruh tidak nyata terhadap panjang malai. Tabel 3 
menunjukkan bahwa panjang malai dari galur-galur yang diuji berkisar antara $23.07 \mathrm{~cm}$ hingga $24.08 \mathrm{~cm}$, dengan reratanya $23.55 \mathrm{~cm}$. Muliarta dan Santoso (2017), menggolongkan panjang malai menjadi tiga golongan yaitu Pendek $(<20 \mathrm{~cm})$, Sedang $(20-30 \mathrm{~cm})$, dan Panjang $(>30 \mathrm{~cm})$. Berdasarkan kriteria tersebut semua galur yang diuji tergolong sedang. Tanaman yang memiliki malai yang panjang akan memberikan gabah yang lebih banyak sehingga berat gabah per rumpun akan meningkat.

Jumlah gabah berisi per malai menunjukkan adanya pengaruh yang tidak nyata antar galur-galur kecuali G5 dengan G1, dan G7. Jumlah gabah berisi antara galur dengan tetua Situ Patenggang berbeda tidak nyata kecuali dengan galur G4 dan G5. Tetua Baas Selem menunjukan perbedaan tidak nyata dengan semua galur pada jumlah gabah berisi. Demikian pula terhadap varietas pembanding G10 (IR20). Tabel 3. menunjukkan jumlah gabah berisi per malai bervariasi dari 80.78 butir hingga 134.35 butir, dengan jumlah reratanya 105.15 butir.

Tabel 3. Hasil uji lanjut parameter jumlah gabah berisi dan hampa per malai, berat 100 butir, berat gabah per rumpun dan hasil gabah (ton $\mathrm{ha}^{-1}$ )

\begin{tabular}{llcccc}
\hline \multicolumn{1}{c}{ Genotipe } & JGB & JGH & B100 & BGPR & Hasil \\
\hline G1 (F9 2/1/1) & $122.45 \mathrm{ab}$ & $17.32 \mathrm{bcd}$ & $2.71 \mathrm{bc}$ & 55.68 & $6.53 \mathrm{a}$ \\
G2 (F9 2/1/2) & $106.30 \mathrm{abc}$ & $17.63 \mathrm{abcd}$ & $2.66 \mathrm{bc}$ & 45.11 & $5.75 \mathrm{ab}$ \\
G3 (F9 3/1) & $98.88 \mathrm{abc}$ & $12.75 \mathrm{~cd}$ & $2.76 \mathrm{abc}$ & 30.77 & $4.29 \mathrm{~d}$ \\
G4 (F9 3/2/2) & $90.82 \mathrm{bc}$ & $8.68 \mathrm{~d}$ & $2.93 \mathrm{a}$ & 48.29 & $5.29 \mathrm{bc}$ \\
G5 (F9 3/2/1) & $80.78 \mathrm{c}$ & $11.38 \mathrm{~cd}$ & $2.85 \mathrm{ab}$ & 45.06 & $4.88 \mathrm{bcd}$ \\
G6 (F9 2/3) & $112.60 \mathrm{abc}$ & $18.15 \mathrm{abc}$ & $2.67 \mathrm{bc}$ & 39.74 & $4.83 \mathrm{bcd}$ \\
G7 (F9 3/4/1) & $124.15 \mathrm{ab}$ & $17.85 \mathrm{abcd}$ & $2.64 \mathrm{c}$ & 50.47 & $6.35 \mathrm{a}$ \\
G8 (Situ Patenggang) & $134.35 \mathrm{a}$ & $26.67 \mathrm{a}$ & $2.70 \mathrm{bc}$ & 40.40 & $5.37 \mathrm{~b}$ \\
G9 (Baas Selem ) & $91.35 \mathrm{bc}$ & $9.83 \mathrm{~cd}$ & $2.78 \mathrm{abc}$ & 41.30 & $4.84 \mathrm{bcd}$ \\
G10 (IR 20) & $89.78 \mathrm{bc}$ & $22.52 \mathrm{ab}$ & $2.35 \mathrm{~d}$ & 35.88 & $4.36 \mathrm{~cd}$ \\
\hline Rerata & 105.15 & 16.28 & 2.71 & 43.27 & 5.25 \\
Maksimum & 134.35 & 26.67 & 2.93 & 55.68 & 6.53 \\
Minimum & 80.78 & 8.68 & 2.35 & 30.77 & 4.29 \\
\hline
\end{tabular}

Keterangan: JGB: jumlah gabah berisi per malai (butir); JGH: jumlah gabah hampa per malai (butir); B100: berat 100 butir (gram); BGPR: berat gabah per rumpun (gram); Hasil $\left(\right.$ tonha $^{-1}$ ). Angka yang diikuti oleh huruf yang sama pada kolom yang sama menunjukkan tidak berbeda nyata menurut hasil uji DMRT pada taraf nyata $5 \%$

Departemen Pertanian (1983) menyatakan bahwa jumlah gabah per malai merupakan komponen hasil tanaman padi, semakin tinggi jumlah gabah per malai maka hasil yang diperoleh akan semakin tinggi pula. Selanjutnya Siregar (1981), menambahkan bahwa untuk mendapatkan daya hasil tinggi atau jumlah gabah berisi yang tinggi diperlukan sifat-sifat yang memberikan dukungan terhadap hasil antara lain batang pendek, jumlah anakan banyak dengan butir gabah yang gemuk dan panjang, sehingga dapat digunakan untuk mendapatkan tanaman padi yang sesuai dengan sasaran pemulia.

Jumlah gabah hampa per malai menunjukkan pengaruh yang nyata antar galur-galur maupun dengan tetua dan varietas pembanding. Pada Tabel 3 tampak bahwa tingkat kehampaan gabah per malai bervariasi antara 8,68 butir hingga 26.67 butir, dengan reratanya sebesar 16.28 butir. Galur yang memiliki jumlah gabah hampa per malainya paling sedikit adalah G4 (8,68 butir) serta menunjukan perbedaan tidak nyata dengan G1, G2, G3, G5, dan 
G7 demikian juga dengan tetua Baas Selem, sedangkan pada galur lainnya memiliki jumlah gabah hampa yang lebih banyak. Menurut Soemartono et al., (1992) menyatakan bahwa kekurangan air pada fase bunting akan mengganggu pembungaan, pembuahan, dan pembentukan malai sehingga mengakibatkan kehampaan. Sedangkan menurut Muliarta (2012), menyatakan bahwa ada perbedaan jumlah gabah hampa per malai antar galur diakibatkan ada perbedaan genetik antar genotipe.

Berat 100 butir gabah berisi memberikan pengaruh yang nyata antar galur-galuryang diujikan maupun dengan kedua tetua (Situ Patenggang dan Baas Selem) maupun dengan varietas pembanding IR 20. Bobot 100 butir gabah tertinggi nampak pada galur G4 serta G3, G5 serta tetua Baas Selem. Galur G10 (IR 20) menunjukan memiliki bobot 100 terendah yaitu 2.35 gram. Pada Tabel 3. tampak bahwa berat 100 butir gabah berisi bervariasi antara 2.35 gram hingga 2.93 gram, dengan reratanya sebesar 2.71 gram. Lim (1965), menggolongkan berat 1000 butir menjadi tiga golongan yaitu Sangat Berat ( $>28$ g), Berat (22-28 g), dan Ringan $(<22$ g). Berdasarkan penggolongan berat 1000 butir tersebut maka semua galur yang diuji termasuk varietas pembanding dan tetua tergolong berat kecuali G4 dan G5 tergolong sangat berat.

Dari 7 galur yang diuji dan 1 varietas pembanding serta 2 tetua tidak memberikan pengaruh yang nyata terhadap berat gabah per rumpun. Kisaran berat gabah per rumpun bervariasi antara 30.77 gram hingga 55.68 gram. Dengan berat reratanya sebesar 43.27 gram. Berat gabah per rumpun sangat dipengaruhi oleh jumlah anakan produktif, jumlah gabah berisi, panjang malai, serta berat 100 butir. Sehingga akan berpengaruh terhadap daya hasil.

Tampak bahwa dari 7 galur yang diuji dan 1 varietas pembanding serta 2 tetua memberikan pengaruh yang nyata terhadap hasil gabah. Tabel 3 menunjukkan bahwa hasil gabah bervariasi antara 4.29 ton per hektar hingga 6.53 ton $\mathrm{ha}^{-1}$. Dengan rerata hasilnya sebesar 5.25 ton $\mathrm{ha}^{-1}$. Galur yang memberikan potensi hasil yang tertinngi adalah galur G1 (F9 2/1/1) sebesar 6.53 ton ha ${ }^{-1}$ dan G7 (F9 3/4/1) 6.35 ton ha ${ }^{-1}$. Galur ini memberikan hasil lebih tinggi dibangdingkan dengan kedua tetuanya yaitu Baas Selem (4.84 ton ha $\left.{ }^{-1}\right)$ dan Situ Patenggang (5.37 ton $\left.\mathrm{ha}^{-1}\right)$

Tingginya daya hasil yang ditunjukkan oleh G1 dikarenakan komponen-komponen hasil yang dimiliki seperti berat gabah per rumpun (55.68 gram), jumlah gabah berisi permalai yaitu 122.45 butir, panjang malai $(24.08 \mathrm{~cm}$ ) dan jumlah anakan produktif per rumpun yaitu 17.53 batang. Sedangkan tingginya daya hasil G7 karena komponen-komponen hasil seperti berat gabah per rumpun (50.47 gram), jumlah gabah berisi per malai yaitu 124.15 butir, panjang malai $(24.02 \mathrm{~cm})$ dan jumlah anakan produktif per rumpun yaitu 18.30 batang.

Hasil penelitian ini sejalan dengan yang dilakukan oleh Rahmah (2013) yang menunjukkan bahwa galur yang memiliki produktivitas lebih tinggi dibandingkan varietas pembanding yaitu galur IPB159-F-1 dan IPB159-F-13 memiliki penampilan karakter yang baik seperti jumlah anakan produktif, panjang malai, serta jumlah gabah berisi per malai. Selanjutnya hasil penelitian yang dilakukan oleh Rizqillah (2013) menunjukkan bahwa Galur C41 (4.77 ton ha $\left.{ }^{-1}\right)$, C42 (4.43 ton ha ${ }^{-1}$ ), dan Galur C49 (4.91 ton ha ${ }^{-1}$ ) memiliki produktivitas yang sama dengan dua varietas pembanding yaitu varietas Inpari-13 (5.17 ton/ha) dan varietas Inpari-19 (5.07 ton $\left.\mathrm{ha}^{-1}\right)$. Sama halnya hasil penenelitian yang dilakukan oleh Noryanti (2012) Galur BM2 (BM6-6-2-3-2) (2,85 ton ha ${ }^{-1}$ ), BM3 (BM6-12-1-2-1) (3.29 ton ha ${ }^{-1}$ ) dan BM4 (BM6-12-1-3-1) (3.34 ton $\mathrm{ha}^{-1}$ ) memiliki produktivitas yang sama dengan dua varietas yang 
digunakan sebagai pembanding, yaitu varietas Selegrang (3.02 ton/ha) dan Aek Sibondang (3.68 ton/ha). Menurut Welsh and Morea (1981) peningkatan hasil panen merupakan sasaran akhir pada setiap program pemuliaan tanaman pangan dan karakter hasil panen mencerminkan penampilan seluruh komponen tanaman. Selanjutnya Siregar (1981), menambahkan bahwa untuk mendapatkan daya hasil tinggi atau jumlah gabah berisi yang tinggi diperlukan sifatsifat yang memberikan dukungan terhadap hasil antara lain batang pendek, jumlah anakan banyak dengan butir gabah yang gemuk dan panjang, sehingga dapat digunakan untuk mendapatkan tanaman padi yang sesuai dengan sasaran pemulia.

\section{KESIMPULAN}

Galur G1(F9 2/1/1) memiliki daya hasil relatif tinggi 6.53 ton $\mathrm{ha}^{-1}$ yang didukung oleh komponen hasil seperti berat gabah per rumpun (55.68 gram), jumlah gabah berisi per malai (122.45 butir), panjang malai $(24.08 \mathrm{~cm})$ dan jumlah anakan produktif per rumpun sebanyak17.53 batang; dan galur G7 (F9 3/4/1) berdaya hasil 6.35 ton ha ${ }^{-1}$ dengan didukung oleh komponen hasil seperti berat gabah per rumpun (50.47 gram), jumlah gabah berisi per malai (124.15 butir), panjang malai $(24.02 \mathrm{~cm})$ dan jumlah anakan produktif per rumpun sebanyak 18.30 batang

\section{UCAPAN TERIMA KASIH}

Terima kasih disampaikan kepada Fakultas Pertanian Universitas Mataram yang telah membiayai penelitian ini melalui dana PNBP 2017.

\section{DAFTAR PUSTAKA}

Abdullah, B., Suwarno, B. Kusnanto, S. Hadis. 2006. Pembentukan Galur Padi Sawah Tipe Baru. http://www.biogen.litbang.deptan.go.id. [28 Januari 2016 ].

Anwar, K., R. Damanhuri, dan S. Partohardjo.1986. Hubungan antara sifat-sifat pertumbuhan padi dengan daya hasil dan tanggapan pemupukan N. Hal. 13-19. Dalam J. Soejitno, Sumarno, M. Amin dan A, Djauhi (Eds) Seminar hasil penelitian tanaman pangan. Balai Penelitian Tanaman Pangan.Bogor

Departemen Pertanian. 1983. Pedoman Bercocok Tanam Padi, Palawija, dan Sayur-sayuran. Satuan Pengendali Bimas. Jakarta.

Departemen Pertanian. 2011. Basis Data Pertanian. Departemen Pertanian. http://database.deptan.go.id/bdsp/hasil_kom.asp.diakses tanggal 7 Juni 2010.

Febrianti. 2013. Makalah Seleksi Gabungan (Bulk). http://www.scibd.com. [19 Desember 2015].

Hermanto,A.2008. Varietas beras organic berdasarkan warna. http://agribisnisganesha.com.p.146. [26 September 2008].

Kristamtini dan H Purwaningsih. 2009. Kandungan besi beras merah dan beras hitam local Yogjakarta. Proseding. Seminar Nasional Padi 2009. Hal: 1011-1018

Lim, G. S. 1965. The Role Of Insecticidies In Rice Integrated Pest Management. Proc. Of the FAO/IRRI Workshop On Judicious Use and Efficient Use On Insecticidies On Rice, IRRI.

Manurung, S. O., Ismunadji M. 1988. Morfologi dan Fisiologi Padi. dalam Manurung, Ismunadji, Roechan, dan Suwardjo (Eds.). Padi Buku 1. Pusat Penelitian dan Pengembangan Tanaman Padi. Badan Penelitian Pengembangan Pertanian. Bogor.

Muliarta A., IGP. dan Siti Permatasari. 2012. Perakitan Varietas Unggul Padi Beras Merah Ampibi Berdaya Hasil dan Kandungan Antosianin Tinggi serta Berumur Genjah. (Laporan Penelitian Hibah Kopetensi tahun 2012). 25 hal.[tidak dipublikasi] 
Muliarta A, IGP., B.B. Santoso, M. Zairin, N Farid., Anggi N. 2015. Perakitan varietas Unggul padi gogo beras hitam berdaya hasil tinggi dan umur genjah. (Laporan Penelitian KKP3N 2015). 45 hal. [tidak dipublikasi]

Muliarta A, IGP., Santoso, B.B, M. Zairin, N Farid., Anggi N. 2016. Perakitan varietas Unggul padi gogo beras hitam berdaya hasil tinggi dan umur genjah. (Laporan Penelitian KKP3N 2016). 50 hal. [tidak dipublikasi]

Muliarta A, IGP., Santoso, B.B. 2017. Budidaya Padi Gogo-Rancah Beras Merah. Arga Puji Press. 65 hal.

Rahmah, R. 2013. Uji Daya Hasil Lanjutan 30 Galur Padi Tipe Baru Generasi F7 Hasil Dari 7 Kombinasi Persilangan. Skripsi Departemen Agronomi dan Hortikultura Fakultas Pertanian IPB. Bogor. 23 hal.

Rizqillah, M. 2013. Uji Daya Hasil Galur-Galur Dihaploid Padi Sawah Berumur Genjah. Skripsi Departemen Agronomi dan Hortikultura Fakultas Pertanian IPB. Bogor. 33 Hal.

Silitonga, T. S. dan Harahap Z. 1998. Perbaikan Varietas Padi. Padi Buku 2. Badan Penelitian dan Pengembangan Pertanian. Pusat Penelitian dan Pengembangan Tanaman Pangan. Bogor.

Siregar H. 1981. Budidaya Tanaman Padi di Indonesia. Sastra Budaya. Bogor. 319 hal.

Soemartono, Nasrullah dan Hartiko. 1992. Genetika Kuantitatif dan Bioteknologi Tanaman PAU-Bioteknologi. Yogyakarta: Gadjah Mada University Press.

Suardi, D. dan Ridwan, I. 2009. Beras hitam, pangan berkhasiat yang belum populer. Warta Penelitian dan Pengembangan Pertanian 31(2): 9-10.

Sunihardi dan Hermanto. 2004. Laporan Tahunan Penelitian dan Pengembangan Tanaman Pangan. Pusat Penelitian dan Pengembangan Tanaman Pangan. Badan Penelitian dan Pengembangan Pertanian.

Suparyono dan A. Setyono. 1993. Padi. Penebar Swadaya. Jakarta.

Syukur, M. S., Sujiprihati, Yunianti R. 2012. Teknik Pemuliaan Tanaman. Bagian Genetika dan Pemuliaan Tanaman. Departemen Agronomi dan Hortikultura IPB. Bogor. 284 hal.

Taslim, Haeruddin. S., Partoharjono, dan Djunainah. 1989. Bercocok Tanam Padi Sawah. Buku Padi 2. Badan Penelitian dan pengembanagan Pertanian. Bogor.652 hal.

Thamrin, T., Imelda S. M., Syahri. 2010. Produktifitas dan Ketahanan Galur Harapan Padi Terhadap Penyakit Tungro di Sumatera Selatan. Balai Pengkajian Teknologi Pertanian Sumatera Selatan. Palembang.

Welsh, J. R. dan Morea. 1981. Dasar-Dasar Genetika dan Pemuliaan Tanaman (Terjemahan dari "Fundamental of Plant Genetic ang Breeding"). Erlangga. Jakarta.

Yoshida, S. 1981. Fundementals Of Rice Crop Science. International Rice Research Institute. Los Banos. Philippines. 